\title{
COMPOSITION AND ANTIMICROBIAL SCREENING OF THE ESSENTIAL OIL FROM THE LEAVES AND STEMS OF Senecio atacamensis Phil. FROM CHILE
}

\author{
JULIO BENITES ${ }^{1,2^{*}}$, FELIPE BRAVO ${ }^{1,2}$, MAURICIO ROJAS $^{1}$, ROSE FUENTES $^{1}$, CRISTINA MOITEIRO $^{2,3}$, \\ FLORENCIA VENÂNCIO ${ }^{3}$
}

\author{
${ }^{1}$ Departamento de Ciencias Químicas y Farmacéuticas, Universidad Arturo Prat, Casilla 121, Iquique, Chile. \\ ${ }^{2}$ Instituto de EtnoFarmacología (IDE), Universidad Arturo Prat. Iquique. Chile. Avenida Arturo Prat 2120. Casilla 121. Iquique. Chile. \\ ${ }^{3}$ Universidade de Lisboa, Faculdade de Ciências, Departamento de Química e Bioquímica e Centro de Química e Bioquímica, Campo Grande, $1749-016$ \\ Lisboa, Portugal
}

(Received: January 26, 2011 - Accepted: May 7, 2011)

\begin{abstract}
An essential oil from Senecio atacamensis Phil. (Asteraceae) was obtained by hydrodistillation of its aerial parts (leaves and stems) and its composition was determined by GC and GC/MS analysis. The identification by GC of the essential oil components, in both leaves and stems respectively, showed $\alpha$-terpinene (36.05\% and 20.57\%); $\alpha$-phellandrene $(27.79 \%$ and $25.37 \%)$, and $p$-cymene (11.85\% and $22.55 \%)$ as the most abundant monoterpenes. Furthermore, the oil was tested for its antimicrobial activity using paper disc diffusion and the dilution broth method, exhibiting moderate inhibition of human pathogenic bacteria.
\end{abstract}

Keywords: Senecio atacamensis Phil., essential oil composition, asteraceae, antibacterial, GC-MS.

\section{INTRODUCTION}

The genus Senecio (Asteraceae) is one of the richest in species among the Angiosperms, with more than 1500 species distributed worldwide in cold and tropical regions, mainly in Europe, Africa, and Central and South America. ${ }^{1}$ Argentina and Chile are the countries with the largest number of representatives, with over 300 species catalogued in each. ${ }^{2,3}$

Many species of the genus Senecio have reportedly been used by Andean people in Chile as traditional remedies for mountain sickness. Several of these species are known by the vernacular name "chachakoma" but Villagran et al., pointed out that given the same name to widely different species of the genus Senecio is basically wrong and misleading. ${ }^{4}$

In this context, Senecio nutans Sch. Bip and Senecio atacamensis Phil., are also called "chachakoma" by local inhabitants, ${ }^{5}$ but they are different plants likely different in their chemical composition. Thus, when the first one is collected in two different regions, namely Arica-Parinacota (Chile) and Arequipa (Peru), different chemical compositions have been obtained. Indeed, the chemical analysis of the oil of Senecio nutans Sch. Bip obtained from AricaParinacota showed predominated terpinen-4-ol (23.7\%), methyl cinnamate (11.4\%) and sabinene $(10.3 \%) ;{ }^{6}$ while the oil obtained from Peru showed that monoterpene hydrocarbons predominated $\alpha$-phellandrene $(15.5 \%), \alpha$-terpinene (15.1\%), sabinene $(13.3 \%), \Delta^{3}$-carene $(8.8 \%)$ and $p$-cymene $(8.8 \%)$ as the main components. ${ }^{7}$ However, as far as we know, the second one (Senecio atacamensis Phil.), a perennial shrub distributed in South American Andean valleys at 3500-4800 $\mathrm{m}$ above sea level, has never been analysed with regard to its essential oil profile.

Since essential oils derived from the leaves, stems, and flowers of some Senecio species show great variation in their chemical composition, ${ }^{6-18}$ the aim of this work was to determine the chemical composition of the essential oil from the leaves and stems of $S$. atacamensis Phil. collected in the region of Tarapacá, Chile. In addition, we explore about a potential biological activity of this essential oil, specifically the antimicrobial capacity against human pathogenic bacteria.

\section{MATERIALS AND METHODS}

\section{Plant material}

S. atacamensis Phil., plants were collected in December 2009 in the Community of Mauque at $4123 \mathrm{~m}$ above sea level, in the region of Tarapacá, Chile. Once collected, the specimens were identified by Prof. Gina Arancio from the Herbarium of the Universidad de la Serena. A voucher sample under accession No. 12602 was deposited in this herbarium.

\section{Essential oil isolation}

Fresh leaves and stems ( $40 \mathrm{~g})$ of each sample were separately subjected to hydrodistillation for $3 \mathrm{~h}$ using a Clevenger-type apparatus. The oil yields were calculated based on a moisture-free basis as $1.04 \%$ and $0.92 \%(w / w)$ from leaves and stems, respectively.

\section{GC and GC-MS analysis}

Chromatographic analysis of the oil from S. atacamensis Phil. was carried out in a Hewlett Packard 5890 series II gas chromatograph equipped with an Automatic Sampler HP 6890 series injector linked to two injector modules, two flame ionization detectors, and two columns, together with a computer station for data treatment. The columns were an OV-101 fused silica $(50 \mathrm{~m}$ x $0.25 \mathrm{~mm}, 0.25 \mu \mathrm{m}$ film thickness) and a Supelco wax10 (30 m x $0.25 \mathrm{~mm}$, $0.25 \mu \mathrm{m}$ film thickness). Oven temperature was held at $70{ }^{\circ} \mathrm{C}$ for $5 \mathrm{~min}$ and then programmed to $220^{\circ} \mathrm{C}$ at $2{ }^{\circ} \mathrm{C} / \mathrm{min}$. The detector and injector were kept at $250^{\circ} \mathrm{C}$ and $240{ }^{\circ} \mathrm{C}$, respectively. Helium was used as carrier gas, at a constant pressure of $55 \mathrm{kPa}$ for the OV-101 and $45 \mathrm{kPa}$ for the Supelco wax 10 . One $\mathrm{mL}$ of oil was injected. The identification of the essential oil components is given in Table 1 and was made by comparison of their retention indices (RI) obtained from calculated values relative to $\mathrm{C}_{8}-\mathrm{C}_{20} n$-alkanes. The intensity of each peak was integrated. The samples were analyzed three times. The average peak areas of all GC signals were added together and the percentage of each component peak was calculated by comparing its average area with the total area.

The GC-MS analysis for identification of compounds was carried out in a Carlo Erba HRGC-MS gas chromatograph equipped with a KRATOS mass detector model MS25RF (sector instrument) and an HP-5MS column (30 m x $0.25 \mathrm{~mm}, 0.25 \mu \mathrm{m}$ film thickness), carrier gas helium, constant pressure 90 $\mathrm{kPa}$, split $1: 20$. The oven was programmed initially from $70^{\circ} \mathrm{C}$ with $2 \mathrm{~min}$ hold up time to the final temperature of $250^{\circ} \mathrm{C}$ with a $5{ }^{\circ} \mathrm{C} / \mathrm{min}$ ramp. The final temperature hold time was $5 \mathrm{~min}$. The inlet and GC/MS interface temperatures were kept at $250^{\circ} \mathrm{C}$ and $280^{\circ} \mathrm{C}$, respectively. The temperature of the $\mathrm{EI} 70 \mathrm{eV}$ source was $200{ }^{\circ} \mathrm{C}$ with full scan $(25-450 \mathrm{~m} / \mathrm{z})$, scan time $0.3 \mathrm{~s}$. The essential oil components were identified by comparing the mass spectra of the analytes with those of authentic standards from the mass spectra of Wiley 6.0 and Mass Spectra Library (NIST 98), and with corresponding data of components from reference oils analyzed in our laboratory. 
Table 1. Percentage composition of the essential oil from the aerial parts (leaves and stems) components identified in Senecio atacamensis Phil., collected in the Tarapacá, Chile.

\begin{tabular}{|c|c|c|c|c|}
\hline Compound & $\mathbf{R I}^{\mathrm{a}}$ & $\begin{array}{c}\text { Leaves } \\
\text { Relative } \\
\text { content } \\
(\%)\end{array}$ & $\begin{array}{c}\text { Stems } \\
\text { Relative } \\
\text { content } \\
(\%)\end{array}$ & $\begin{array}{l}\text { Identification } \\
\text { method }\end{array}$ \\
\hline$\alpha$-Thujene & 915 & 0.37 & 0.26 & RI, MS \\
\hline$\alpha$-Pinene & 924 & 4.04 & 5.76 & RI, MS \\
\hline Sabinene & 963 & 0.40 & 0.91 & RI, MS \\
\hline$\beta$-Pinene & 970 & 3.81 & 7.62 & RI, MS \\
\hline$\beta$-Myrcene & 978 & 0.91 & 0.92 & RI, MS \\
\hline$\alpha$-Phellandrene & 1000 & 27.79 & 25.37 & RI, MS \\
\hline$\Delta^{3}$-Carene & 1007 & $\mathrm{t}$ & 0.19 & RI, MS \\
\hline$\alpha$-Terpinene & 1013 & 36.05 & 20.57 & RI, MS \\
\hline p-Cymene & 1016 & 11.85 & 22.55 & RI, MS \\
\hline Limonene & 1023 & 1.25 & 2.29 & RI, MS \\
\hline (Z)- $\beta$-Ocimene & 1036 & $\mathrm{t}$ & 0.39 & RI, MS \\
\hline (E)- $\beta$-Ocimene & 1037 & $\mathrm{t}$ & 0.23 & RI, MS \\
\hline$\gamma$-Terpinene & 1049 & 0.73 & 0.67 & RI, MS \\
\hline Terpinolene & 1080 & $\mathrm{t}$ & 0.52 & RI, MS \\
\hline Terpinen-4-ol & 1164 & 0.91 & 0.67 & RI, MS \\
\hline$\alpha$-Humulene & 1460 & 0.16 & 0.3 & RI, MS \\
\hline Germacrene D & 1477 & 0.55 & 1.31 & RI, MS \\
\hline$\alpha$-Muurolene & 1499 & 0.39 & 0.41 & RI, MS \\
\hline$\delta$-Cadinene & 1521 & 1.27 & 1.59 & RI, MS \\
\hline Spathulenol & 1574 & 0.47 & 0.93 & RI, MS \\
\hline T-Cadinol & 1635 & 2.29 & 1.49 & RI, MS \\
\hline a-Cadinol & 1648 & 1.81 & 1.91 & RI, MS \\
\hline T-Muurolol & 1663 & $\mathrm{t}$ & 0.46 & RI, MS \\
\hline Tremetone & 1700 & 0.96 & 1.27 & RI, MS \\
\hline
\end{tabular}

${ }^{\text {a }}$ Retention as determined on the OV-101 column using the homologous series of n-alkanes $\left(\mathrm{C}_{8-20}\right) \mathrm{t}=$ traces.

\section{Antimicrobial screening}

Two techniques were used to test the antimicrobial activity of the $S$. atacamensis oils: the paper disc diffusion and the dilution broth methods. The minimum inhibitory concentration (MIC) was determined by the latter method.

\section{Bacterial strains}

The microorganisms used were Escherichia coli (ATCC 25922), Klebsiella pneumoniae (ATCC 23357), Staphylococcus aureus (ATCC 25923) and Enterococcus faecalis (ATCC 29212).

\section{Paper disc diffusion}

The antimicrobial activity was carried out according to the disc diffusion assay, the bacterial strains were maintained in agar at room temperature. 2.5 $\mathrm{mL}$ of every bacteria inoculum were incubated in Mueller-Hinton agar at 37 ${ }^{\circ} \mathrm{C}$ for 18 hours. The bacterial inoculum was adjusted to the McFarland $\mathrm{N}^{\circ}$ 0.5 turbidity standard $(10 \mathrm{cfu} / \mathrm{mL})$. Every inoculum was spread over plates containing Mueller-Hinton agar and a filter paper disc. The plates were left for $30 \mathrm{~min}$ at room temperature and then incubated at $37{ }^{\circ} \mathrm{C}$ for $24 \mathrm{~h}$. The inhibitory zone around the disc was measured and expressed in $\mathrm{mm}$. A positive control was also assayed to check the sensitivity of the tested organisms using the antibiotic vancomicyn.

A negative control was also included in the test using a filter paper disc saturated with DMSO to check possible activity of this solvent against the bacteria assayed. The experiments were repeated at least twice.

\section{Determination of the minimum inhibitory concentration (MIC)}

The antimicrobial activity of the essential oil was determined by the broth dilution method. ${ }^{19}$ The following concentrations were tested: $200,100,50,25$, and $12.5 \mu \mathrm{g} / \mathrm{mL}$. After incubation the microbial growth was examined. The results are expressed in Minimum Inhibitory Concentration (MIC), the lowest concentration of essential oil yielding no visible growth. The bactericidal/ bacteriostatic activity was determined by subcultivation of the samples in normal culture media at appropriate temperature and incubation times. The MIC of each essential oil was determined at least twice. The essential oil was dissolved in dimethylsulfoxide (DMSO) (Merck). Cefazolin was used as a positive control, at the same essential oil concentration.

\section{RESULTS AND DISCUSSION}

As part of our research focusing on the evaluation of the popular use of Chilean medicinal plants that grow in the Chilean Altiplano, the study of the chemical composition of the essential oils and the antimicrobial screening of several plants grows Chile and Perú was undertaken for a long time..$^{20-22}$

In this context, the results of the GC and GC-MS analysis of the essential oil of the leaves and stems from Senecio atacamensis Phil., are listed in Table 1. The analysis showed the presence of twenty-four compounds, fifteen of which were identified as monoterpenes, eight as sesquiterpenes, and one as diterpene. The essential oil from the leaves showed a very similar composition pattern as that obtained from the stems. The leaves showed that $\alpha$-terpinene is the most abundant monoterpene, $36.05 \%$, and together with $\alpha$-phellandrene, $27.79 \%$, and $p$-cymene, $11.85 \%$, they make up $75.69 \%$ of the total oil. The essential oil from the stems had $\alpha$-phellandrene as the most abundant monoterpene, $25.37 \%$, and together with $p$-cymene, $22.55 \%$, and $\alpha$-terpinene, $20.57 \%$, they make up $68.49 \%$ of the total oil. Analysis of the oils showed that they are predominantly monoterpnoid in nature, like those from some other species of the genus Senecio. ${ }^{11,23,24}$

When the composition of the oil obtained from S. atacamensis Phil., was compared to that from other "chachakoma" specimens like S. nutants Sch.Bip., also collected at high altitudes, a similar profile was found. Indeed, the three main components identified in $S$. atacamensis were also observed in $S$. nutans although in less percentage. However, we also noted that both sabinene and $\Delta^{3}$-carene, two monoterpenes well expressed in $S$. nutans were almost inexistent in S. atacamensis.

Traditionally essential oils have been explored for some standard biological activities like antimicrobial, fungicide and antioxidant as well. In this paper we were interested to know whether essential oil from S. atacamensis has or not a potential antimicrobial activity. To this end, the antibacterial activity of $S$. atacamensis essential oil from the leaves and stems was evaluated against human pathogens, two gram-negative (E. coli and K. pneumoniae) and two gram-positive ( $S$. aureus and E. faecalis). These pairs of microorganisms are both morphologically and physiologically different, so the results obtained are representative of the antibacterial activity of the oil.

In Table 2 is shown that the essential oil from the stems exhibited good antibacterial activity against on $K$. pneumoniae and $S$. aureus, but the essential oil from the leaves only exhibited antibacterial activity against $K$. pneumonia. $E$. coli and E. faecalis were the most resistant to both oils. S. aureus and $E$. faecalis are considered responsible for causing several human infections and are known to be resistant to some kinds of antibacterial treatment using commercial patented antibiotics.

Table 2. Paper disc diffusion of the essential oil of aerial parts (leaves and stems) from Senecio atacamensis Phil.

\begin{tabular}{|l|c|c|c|c|}
\hline Microorganism & $\begin{array}{c}\text { Gram } \\
-/+\end{array}$ & \multicolumn{2}{|c|}{ Inhibition zone $^{\mathrm{a}}$} & \\
\hline & & \multicolumn{2}{|c|}{ Essential oil $(3 \mathrm{mg} / \mathrm{mL})$} & $\begin{array}{c}\text { Standard } \\
\text { nntibiotic }^{\mathrm{c}}\end{array}$ \\
\hline Escherichia coli & G- & Leaves & Stems & Va \\
\hline Klebsiella pneumoniae & G- & $18 \pm 1.4^{\mathrm{a}}$ & $18.5 \pm 0.7^{\mathrm{a}}$ & $19 \pm 0.1^{\mathrm{a}}$ \\
\hline Staphylococcus aureus & $\mathrm{G}+$ & $\mathrm{nd}$ & $10.5 \pm 0.7^{\mathrm{a}}$ & $21 \pm 0.1^{\mathrm{a}}$ \\
\hline Enterococcus faecalis & $\mathrm{G}+$ & $\mathrm{nd}$ & $\mathrm{nd}$ & $25 \pm 0.1^{\mathrm{a}}$ \\
\hline
\end{tabular}

a Diameter $=6 \mathrm{~mm}$; average of two consecutive assays. Values are given as mean $\pm \mathrm{SD}$

${ }^{\mathrm{b}} \mathrm{nd}=$ antibacterial activity not detected.

${ }^{\mathrm{c}}$ Standard antibiotic: $\mathrm{Va}=$ Vancomycin $30 \mathrm{mg}$.

It should be noted that the MIC values of the essential oils from the leaves and stems were in the range of $150-300 \mathrm{mg} / \mathrm{mL}$ (table 3). These values are one order of magnitude lower than to those observed by standard antibiotics (12-20 $\mathrm{mg} / \mathrm{mL}$ ).

The essential oils of aerial parts (leaves and stem) did not exhibit antibacterial activity against $E$. coli. Leaf oil inhibited the growth of $S$. aureus 
and E. faecalis with bacteriostatic activity at 260 and $152.9 \mu \mathrm{g} / \mathrm{mL}$. Stems oil exhibited good antibacterial activity against two Gram-positive and one Gram-negative organism. We have not explanation for these differences in the susceptibility of the test microorganisms to the essential oils, but as suggested by Gao et al., 2011 and Cox et al., 2000, the higher resistance among Gramnegative bacteria can be ascribed to their cell wall structure and outer membrane arrangement as well as on the type of essential oil. ${ }^{25,26}$

Although the mechanism of action of terpenes is not fully understood, it is thought to involve membrane disruption by the lipophilic compounds. ${ }^{27}$ The antibacterial activity may be related to the chemical proportion of the main compounds, $\alpha$-terpinene, $\alpha$-phellandrene, and $p$-cymene, as well to the minor components present in our essential oil.

From a chemical point of view, the essential oils are quite complex mixtures containing a large variety of constituents. Then, it may be argued that the observed antimicrobial effect is resulting from the activity of several active compounds as well as to potential synergistic effects between them. Thus, as nicely discussed by Jiang et al. ${ }^{28}$ this complexity in chemical composition makes it often difficult to explain the biological activities shown by essential oils.

Table 3. Minimum inhibitory concentration (MIC) of essential oil of aerial parts (leaves and stems) from Senecio atacamensis Phil.

\begin{tabular}{|c|c|c|c|c|}
\hline \multirow[t]{3}{*}{ Microorganism } & Gram -/+ & ${ }^{\mathrm{a}} \mathrm{MICs}$ & & \multirow{3}{*}{$\begin{array}{c}\begin{array}{c}\text { Standard } \\
\text { antibiotic }\end{array} \\
\text { Cef }\end{array}$} \\
\hline & & \multicolumn{2}{|c|}{${ }^{\mathrm{b}}$ Essential oil } & \\
\hline & & Leaves & Stems & \\
\hline Escherichia coli & G- & ${ }^{\mathrm{c}}$ nd & nd & nd \\
\hline Klebsiella pneumoniae & G- & 338.8 & 195.6 & 12.5 \\
\hline Staphylococcus aureus & $\mathrm{G}^{+}$ & 260.7 & 164.1 & 12.5 \\
\hline Enterococcus faecalis & $\mathrm{G}+$ & 152.9 & 162.6 & 200 \\
\hline
\end{tabular}

a Minimum inhibitory concentration (MIC).

${ }^{\mathrm{b}} \mathrm{MIC}$ of essential oil (values in $\mathrm{mg} / \mathrm{mL}$ ).

${ }^{\mathrm{c}} \mathrm{nd}$, antibacterial activity not detected.

${ }^{\mathrm{d}}$ standard antibiotic: Cef $=$ Cefazolin

\section{ACKNOWLEDGEMENTS}

This study was supported by DI-UNAP and by Conicyt-MEC, 80100002 .

\section{REFERENCES}

1. J. Soukup, Vocabulario de los Nombres Vulgares de la Flora Peruana y Catalogo de los Generos, Editorial Salesiana: Lima, 1987; 393-394.

2. C. Pérez, A. M. Agnese, J. L. Cabrera. J. Etnopharmacol. 66: 91-96, (1999)
3. A. Urzúa, L. Andrade. Biochem. Syst. Ecol. 29: 865-867. (2001)

4. C. Villagrán, V. Castro, G. Sánchez, M. Romo, C. Latorre, L. F. Hinojosa. Estudios Atacameños. 16: 7-105, (1998).

5. C. Villagrán. Ciencia Indígena de los Andes del Norte de Chile, Editorial Universitaria: Chile, 2004; 2008-2009.

6. H. Niemeyer, S. Teillier. Aromas de la Flora Nativa de Chile, Editado por Universidad de Chile y FIA, 2007; 310-311.

7. V. De Feo, E. U. Soria, R. U. Soria, F. Senatore. Flavour Fragr. J. 18: 234-236, (2003).

8. R. R. Vera, S. J. Laurent, D. J. Fraisse. J. Essent. Oil Res. 6: 21-25, (1994)

9. N. Mengi, S. N. Garg, S. K. Agarwal, C. S. Mathela. J. Essent. Oil Res. 7: 511-514, (1995).

10. V. De Pooter, L. F. De Buyck, N. M. Schamp, E. Aboutabi, A. De Bruyn, S. Z Husain. Flavour Frag. J. 1: 159-163, (2006).

11. A. M. El-Shazly, J. Pharm. Sci. 8: 1-8, (1999).

12. K. H. C. Baser, B. Demirci. J. Essent. Oil Res. 16: 558-559, (2004).

13. V. T. Balzaretti, A. Arancibia, A. M. E. Marchiaro, M. S Feijoo. Molecules 5: 459-461, (2000)

14. M. Mirza, N. Z. Baher. J. Essent. Oil Bearing Plants 11: 179-183; (2008).

15. A. J. Belaunde, J. G. Sandoval, L. De Martino, F. Senatore, V. De Feo. J. Essent. Oil Bearing Plants 10: 332-338, (2007).

16. G. Fernández-Zúñiga, I. Fernández-Valderrama, G. B Hammond. Rev. Latinoam. Quim. 25: 14-16, (1996).

17. J. C. Chalchat, Z. A. Maksimovic, S. D. Petrovic, M. S. Gorunovic. J. Essent. Oil Res. 16: 227-228, (2004).

18. D. Nori-Shargh, S. Raftari, F. Deyhimi. Flavour Frag. J. 23: 357-359, (2008).

19. P. A. Wayne, Performance standards for antimicrobial susceptibility testing. Ninth informational supplement NCCLS document M100-S9. National Committee for Clinical Laboratory Standards, 2008.

20. L. Rojo, J. Benites, A. Rodrigues, F.Venancio, L.Ramalho, A.Teixeira, S. Feio, M.C.Costa. J. Essent. Oil Res. 18, 695-697, (2006).

21. J. Benites, C. Moiteiro, G. Miguel, L. Rojo, J. López, F. Venâncio, L. Ramalho, S. Feio, S. Dandlen, H. Casanova, I. Torres. J. Chil. Chem. Soc. 54, 379-384, (2009).

22. J. Benites, J. Lopez, L. Rojo, P. Diaz, M. Rojas, F. Venâncio, C. Moiteiro. Chem. Nat. Compd. 46, 838-839, (2011).

23. C. Perez, A.M. Agnese, J. L. Cabrera. J. Ethnopharmacol. 66: 91-96, (1999).

24. M. H. Grace, A. M. Khattab. Egypt. J. Pharm. Sci. 39: 253-266, (1998).

25. S. D. Cox, C. M. Mann,. J. L. Markham, H. C. Bell, J. E. Gustafson, J. R. Warmington, S. G. Wyllie. J. Appl. Microbiol. 88, 170-175, (2000).

26. Ch. Gao, Ch. Tian, Y. Lu, J. Xu, J. Luo, X Guo. Food Control. 22, $517-$ $522,(2011)$.

27. M. M. Cowan. Clin. Microbiol. Rev., 12: 564-582, (1999)

28. Y. Jiang, N. Wua, Y-J Fua, W. Wang, M. Luo, Ch-J. Zhao, Y-G. Zu, X-L. Liu. Environ. Toxicol. Pharmacol. (2011). doi:10.1016/j.etap.2011.03.011 